\title{
Terör Olaylarının Finansal Piyasalar Üzerine Etkisi
}

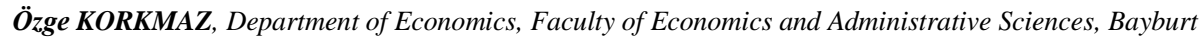
University,Turkey; e-mail: ozgekorkmaz@gmail.com

Deniz ERER, Department of Economics, Graduate School of Social Sciences, Ege University, Turkey; e-mail: denizerer@hotmail.com

Elif ERER, Department of Economics, Graduate School of Social Sciences, Ege University, Turkey; e-mail: elif_erer_@hotmail.com

\section{The Effects of Terrorist Attacks on Financial Markets}

\begin{abstract}
In this study, we examined the volatility effect of terrorist incidents on Istanbul Gold Exchange, ISE100 and on the index yields of the sub-sectors in Turkey. Since negative and positive events have different effects on volatility, EGARCH and GJR-GARCH models used. Because of the study, it has seen that the terrorist attacks which occured in Turkey do not have statistically significant effects on the volatility of Istanbul Gold Exchange, ISE100 and of the sub-sectors. In addition, it has found that gold, service and technology indices have affected by only positive events; however, both negative and positive ones affect industrial and financial indices.
\end{abstract}

Keywords

Volatility Models, Equity Market, Gold Market, Financial Market, Terrorist Attack.

JEL Classification Codes : C22, C58, D53, K42.

\section{$\ddot{\mathbf{O z}}$}

Bu çalışmada, Türkiye'de meydana gelen terör olaylarının İstanbul Altın Borsası, BIST100 ve alt sektör endeks getirileri üzerindeki oynaklık etkisi incelenmiştir. Çalışmada, negatif ve pozitif olayların oynaklık üzerindeki etkilerinin farklı olması nedeniyle EGARCH ve GJR-GARCH modelleri kullanılmıştır. Çalışmanın sonucunda, Türkiye'de yaşanan terör olaylarının BIST 100, alt sektör ve İstanbul Altın Borsası endeks oynaklığı üzerinde istatistiksel olarak anlamlı bir etkiye sahip olmadığı görülmüştür. Ayrıca altın, hizmet ve teknoloji sektör endekslerinin sadece pozitif yönlü; sınai ve mali sektör endekslerinin ise hem negatif hem de pozitif yönlü haberlerden etkilendiği tespit edilmiştir.

Anahtar Sözcükler $\quad$ : Oynaklık Modelleri, Hisse Senedi Piyasası, Altın Piyasası, Finansal Piyasalar, Terör Olayları. 


\section{Giriş}

Terörizm, korku, tehdit ve yıldırma yoluyla politik, ekonomik, dinsel ya da sosyal amaç elde etmek amacıyla devlet dişında bir aktör tarafindan gerçekleştirilen şiddet veya illegal gücün tehdit/fiili kullanımı olarak tanımlanmaktadır (Procasky \& Ujah, 2016: 254). Benzer şekilde, iktisat literatürüne göre, terörist saldırılar zaman içerisinde sıkça gerçekleşmeyen ve ekonomideki oynaklığı arttıran olaylar olarak ele alınmaktadır. Ancak bu durumun ülkeler açısından değiştiği görülmektedir. Örneğin İsrail ve Amerika gibi zengin ülkeler daha sık hedef haline gelmektedirler. Ekonomisi güçlü olan ülkeler terörist saldırıların hedefinde yer alırken zayıf ekonomileri olan ülkeler terörist saldırılardan daha fazla zarar görmektedir (Llussa \& Tavares, 2011: 52). Terör can kaybı ve bedensel yaralanmalar dışında ekonomik maliyetlere sahiptir. Kolias vd. (2011: 532)'e göre,

“terörist saldırıların ortaya çıkardı̆̆ı maliyetler, teröre karşı güvenlik sağlamak amacıyla gerekli olan çok büyük miktardaki kaynaklar, terörist saldırlların neden olduğu sermaye birikimi ve mal kaybı olarak ifade edilebilir. Aynı zamanda terör eylemlerinin ekonomik göstergeleri, sektörleri, büyüme ve yatırım faaliyetlerini olumsuz yönde etkileyen çok sayıda ekonomik sonuçları vardır."

Terörist saldırılar, askeri istilalar ve diğer öngörülemeyen yıkıcı olaylar hisse senetleri ve tahviller üzerinde de önemli sonuçlara sahip olabilmektedir. Bilindiği üzere hisse senedi fiyatları yatırımcıların beklentilerini ve gelecekle ilgili endişelerini yansıtmaktadır. Dolayısıyla, hisse senedi fiyatındaki hareketler ekonominin genelinde bir tsunami etkisi yaratabilmektedir (Chen \& Siems: 2004, 349). Bu bağlamda terör, bir ülkenin belirsizlik düzeyinin artmasına ve terörle mücadelede savunma harcamalarını artırmasına, sermaye birikimini azaltmasına, sektörlerin ve finansal piyasaların olumsuz etkilenmesine neden olmaktadır (Abadie \& Gardeazabal, 2008: 2). Bu nedenle terör olaylarının etkilerinin araştırılması oldukça önemlidir.

Terörizmin finansal piyasalar ve ekonomi üzerindeki etkileri literatürde çok fazla ele alınan bir konu olmamakla birlikte bu durum 11 Eylül saldırılarından sonra değişmiştir. Çünkü 11 Eylül 2001 yılında New York'ta ikiz kulelere gerçekleştirilen terörist saldırılar, 2004 yılında Madrid ve 2005 yılında Londra'da meydana gelen saldırılar ile terör riskinin piyasalar ve ekonomi üzerindeki etkilerini araştıran çalışmaların ağırlık kazandığı gözlenmektedir. Bir diğer ifadeyle bu olaylar, terör riskinin yatırımcılar ve finansal kurumların karşılaşabileceği yeni bir risk olarak ele alınmasına neden olmuştur (Chesney vd., 2011: 253).

Terör olaylarının ekonomik etkileri göz ardı edilemez niteliktedir. Benzer şekilde finansal piyasalara olan etkisi de dikkate alınabilecek boyuttadır. Bu bağlamda, çalışmada 02 Ocak 2009-31 Aralık 2014 döneminde Türkiye'de meydana gelen terör olaylarının altın, hisse senedi piyasaları ile alt sektör endeks getirilerinin oynaklığı üzerindeki etkileri araştırılmak istenmiştir. 


\section{Literatür}

Terör olaylarının ekonomiye ve turizm sektörüne etkilerini inceleyen birçok çalışmanın var olduğu söylenebilir. Bu doğrultuda, terör olaylarının turizm sektörüne etkilerini inceleyen çalışmaların bir kısmı Tablo 1'de; makroekonomik etkilerini inceleyen çalışmaların bir kısmı ise Tablo 2'de özet olarak sunulmuştur.

Tablo: 1

Terörün Turizm Sektörüne Etkisini İnceleyen Çalışmaların Özeti

\begin{tabular}{|c|c|c|c|}
\hline Yazar & $\begin{array}{l}\text { Dönem-Ülke- } \\
\text { Yöntem }\end{array}$ & Değişkenler & Sonuç \\
\hline $\begin{array}{l}\text { Emsen ve } \\
\text { Değer } \\
(2004)\end{array}$ & $\begin{array}{l}\text { 1984-2001, } \\
\text { Türkiye, En } \\
\text { Küçük Kareler } \\
\text { Yöntemi }\end{array}$ & $\begin{array}{l}\text { Reel döviz kuru, terör olayları } \\
\text { sayısı, yabancı ülke gelirlerini } \\
\text { temsilen OECD ülkelerinde kişi } \\
\text { başına düşen gelir, Türkiye'nin } \\
\text { yıllık turizm geliri, tüketici fiyat } \\
\text { endeksi }\end{array}$ & $\begin{array}{l}\text { Yabancı ülke kişi başına gelir } \\
\text { düzeyindeki artışlar Türkiye'nin turizm } \\
\text { gelirlerini pozitif yönde; terör } \\
\text { olaylarındaki artışı turizm gelirlerini } \\
\text { negatif yönde etkilediği sonucuna } \\
\text { ulaşılmıştır. }\end{array}$ \\
\hline $\begin{array}{l}\text { Feridun } \\
(2011)\end{array}$ & $\begin{array}{l}\text { 1986-2006, } \\
\text { Türkiye, ARDL } \\
\text { Sinır Testi }\end{array}$ & $\begin{array}{l}\text { Terörist saldırı sayısı, ülkeye giren } \\
\text { turist sayısı }\end{array}$ & $\begin{array}{l}\text { Turizm ve terörizm arasında uzun } \\
\text { dönemli negatif bir ilişki vardır. }\end{array}$ \\
\hline $\begin{array}{l}\text { Güvenek ve } \\
\text { Alptekin } \\
(2015)\end{array}$ & $\begin{array}{l}\text { 1993-2008, } \\
\text { Türkiye, } \\
\text { Müdahale } \\
\text { Analizi }\end{array}$ & $\begin{array}{l}\text { Terörist saldırı sayısı, ülkeye giren } \\
\text { turist sayısı }\end{array}$ & $\begin{array}{l}\text { Terörist saldırılarının ülkeye giren turist } \\
\text { sayısı üzerinde anlamlı bir etkisi yoktur. }\end{array}$ \\
\hline $\begin{array}{l}\text { Parida } \\
\text { vd.(2015) }\end{array}$ & $\begin{array}{l}\text { 1980-2011, } \\
\text { Hindistan, } \\
\text { ARDL Sınır } \\
\text { Testi }\end{array}$ & $\begin{array}{l}\text { Terörist saldırıların sayısı, ülkeye } \\
\text { giren turist sayısı, kişi başına düşen } \\
\text { gelir, sabit telefon abone sayısı, } \\
\text { turizmden elde edilen gelir }\end{array}$ & $\begin{array}{l}\text { Terörist saldırılar ve ülkeye gelen turist } \\
\text { sayısı arasında negatif, ekonomik } \\
\text { kalkınma ve turist sayısı arasında ise } \\
\text { pozitif bir ilişki vardır. }\end{array}$ \\
\hline $\begin{array}{l}\text { Ahmet ve } \\
\text { Anwar } \\
(2016)\end{array}$ & $\begin{array}{l}\text { 1989-2011, } \\
\text { Pakistan, } \\
\text { Doğrusal } \\
\text { regresyon }\end{array}$ & $\begin{array}{l}\text { Terörist saldırı sayısı, ülkeye giren } \\
\text { turist sayısı, sosyal sabit sermaye }\end{array}$ & $\begin{array}{l}\text { Terörist saldırılar turizmi negatif yönde } \\
\text { etkilerken, sosyal sabit sermaye turizm } \\
\text { endüstrisini } \quad \text { olumlu } \\
\text { etkilemektedir. }\end{array}$ \\
\hline $\begin{array}{l}\text { Feridun } \\
(2016)\end{array}$ & $\begin{array}{l}\text { 1980-2006, } \\
\text { Türkiye, ARDL } \\
\text { Sinır } \quad \text { Testi, } \\
\text { VECM }\end{array}$ & $\begin{array}{l}\text { Terörist saldırı sayısı, okullaşma } \\
\text { oranı, yoksullaşma oranı }\end{array}$ & $\begin{array}{l}\text { Terörist saldırılar ile okullaşma oranı } \\
\text { arasında uzun dönemli bir ilişki } \\
\text { mevcutken, yoksullaşma ile terörist } \\
\text { saldırılar arasında bir ilișki yoktur. }\end{array}$ \\
\hline $\begin{array}{l}\text { Serçek ve } \\
\text { Serçek } \\
(2016)\end{array}$ & $\begin{array}{l}\text { 2009-2014, } \\
\text { Türkiye, Trend } \\
\text { Analizi ile talep } \\
\text { tahmini }\end{array}$ & Yerli ve yabancı turist sayısı & $\begin{array}{l}\text { Çözüm süreci Güneydoğu Anadolu } \\
\text { Bölgesi'ne olan turizm talebini yerli } \\
\text { turist sayısı dikkate alındığında pozitif } \\
\text { yönde etkilediği sonucuna ulaşılmıştır. }\end{array}$ \\
\hline
\end{tabular}




\section{Tablo: 2}

\section{Terörün Makroekonomik Etkilerini İnceleyen Çalışmaların Özeti}

\begin{tabular}{|c|c|c|c|}
\hline Yazar & Dönem-Ülke-Yöntem & Değişkenler & Sonuç \\
\hline $\begin{array}{l}\text { Persitz } \\
(2007) \text {, }\end{array}$ & $\begin{array}{l}\text { 1980-2003 dönemi; İsrail; } \\
\text { VAR analizi }\end{array}$ & $\begin{array}{l}\text { Kişi başına düşen GSYİH, } \\
\text { özel nihai tüketim } \\
\text { harcamaları, yatırımlar, } \\
\text { kamu harcamaları, ihracat, } \\
\text { ithalat, nüfus yoğunluğu, } \\
\text { sektörlere göre GSYİH } \\
\text { oranı değişkenleri }\end{array}$ & $\begin{array}{l}\text { Çalışmada İsrail'de terörün olduğu } \\
\text { durum ile olmadığ } \text { durum } \\
\text { karşılaştırılmış ve 1994'ten sonra } \\
\text { Filistin'in şiddet eylemlerinin } \\
\text { olmaması durumunda ülkenin } \\
2003: 03 \text { dönemindeki kişi baş1 } \\
\text { GSYİ oranı \%8.6 daha fazla } \\
\text { olabileceği sonucuna ulaşılmıştır. }\end{array}$ \\
\hline $\begin{array}{l}\text { Caruso ve } \\
\text { Schneider } \\
(2011),\end{array}$ & $\begin{array}{l}\text { 1994- } 2007 \text { dönemi,12 } \\
\text { Avrupa ülkesi; Panel } \\
\text { analizi }\end{array}$ & $\begin{array}{l}\text { Kişi başına düşen gelir, } \\
\text { işsizlik, genç işsizlik ve } \\
\text { enflasyon }\end{array}$ & $\begin{array}{l}\text { Ekonomik büyüme, enflasyon ve } \\
\text { işsizlik ile terör saldırıları arasında } \\
\text { negatif ancak genç işsizlik ile terör } \\
\text { saldırıları arasında pozitif bir ilişki } \\
\text { vardır.. }\end{array}$ \\
\hline $\begin{array}{l}\text { Freytag vd. } \\
(2011),\end{array}$ & $\begin{array}{l}\text { 1971-2007 dönemi için } 110 \\
\text { ülke; Panel veri analizi }\end{array}$ & $\begin{array}{l}\text { Kişi başına düşen GSYİH, } \\
\text { tüketim düzeyi, ticari } \\
\text { açılık, yatırım, politik } \\
\text { istikrarsızlık, reel GSYIH } \\
\text { içinde kamunun } \\
\text { büyüklüğü, nüfus, din } \\
\text { değişkenleri }\end{array}$ & $\begin{array}{l}\text { Analiz sonucunda ülkelerin terörizmi } \\
\text { azaltmaları için ekonomik büyüme ve } \\
\text { kalkınma düzeylerinin yüksek olması } \\
\text { gerektiği tespit edilmiştir. }\end{array}$ \\
\hline $\begin{array}{l}\text { Shahbaz } \\
\text { (2013), }\end{array}$ & 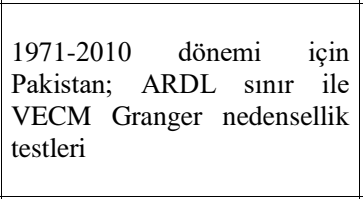 & $\begin{array}{l}\text { Terör, ekonomik büyüme } \\
\text { ve enflasyon }\end{array}$ & $\begin{array}{l}\text { Enflasyon, ekonomik büyüme ve } \\
\text { terörizm arasında uzun dönemli bir } \\
\text { ilişki mevcuttur. Enflasyon ve terörist } \\
\text { saldırılar arasında pozitif bir ilişki } \\
\text { vardır ve en büyük etkiyi ekonomik } \\
\text { büyüme sağlamaktadır. }\end{array}$ \\
\hline $\begin{array}{l}\text { Altay vd. } \\
(2013),\end{array}$ & $\begin{array}{l}\text { 1996-2010 dönemi için } \\
\text { Türkiye, Misır ve Sudi } \\
\text { Arabistan; Panel veri analizi }\end{array}$ & $\begin{array}{l}\text { Terör endeksi, ihracat, } \\
\text { ithalat, ekonomik büyüme, } \\
\text { doğrudan yabancı } \\
\text { yatırımlar, turizm, kişi } \\
\text { başına düşen gelir ve } \\
\text { işsizlik }\end{array}$ & $\begin{array}{l}\text { Terör makroekonomik değişkenler } \\
\text { üzerinde negatif etkilidir. }\end{array}$ \\
\hline $\begin{array}{l}\text { Akınc1 vd. } \\
(2015)\end{array}$ & 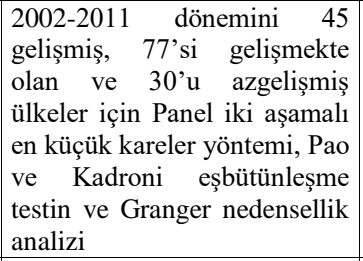 & $\begin{array}{l}\text { Global terör endeksi, } \\
\text { enflasyon oranı ve } \\
\text { Amerikan doları bazında } \\
\text { GSYİH değişkenleri }\end{array}$ & $\begin{array}{l}\text { Terörün, doğrudan ve dolaylı } \\
\text { yatırımları negatif etkilemektedir ve, } \\
\text { değişkenler arasında uzun dönemli ve } \\
\text { tek yönlü bir ilişki mevcuttur. }\end{array}$ \\
\hline $\begin{array}{l}\text { Kurt ve } \\
\text { Karagöl } \\
(2015),\end{array}$ & $\begin{array}{l}\text { 1989-2002 dönemi için düşük } \\
\text { ve yüksek gelire sahip ülkeler } \\
\text { için panel veri analizi }\end{array}$ & $\begin{array}{l}\text { Büyüme oranı, sabit } \\
\text { sermaye oluşumu, } \\
\text { savunma harcamaları, } \\
\text { terör olaylarının sayısı ile } \\
\text { nüfus artış oranı }\end{array}$ & $\begin{array}{llr}\text { Analiz } & \text { sonucunda } & \text { savunma } \\
\text { harcamalarının } & \text { ve terörün } & \text { ekonomik } \\
\text { istikrarsızlığ } & \text { arttırdığı } & \text { sonucuna } \\
\text { ulaşılmıştır. } & & \\
\end{array}$ \\
\hline
\end{tabular}

Tablo 1'den ve Tablo 2'den görüldüğü üzere, terör olayları ekonomiyi ve turizm sektörünü negatif yönde etkilemektedir. Literatürde terör olaylarının finansal piyasalar üzerindeki etkilerini inceleyen çalışmaların da var olduğu söylenebilmektedir. Literatür 
incelemesinin yapıldığı bu kısımda, terör olaylarının finansal piyasalar üzerindeki etkilerini inceleyen çalışmalara değinilmiştir.

Chen ve Siems (2004) çalışmalarında terörün küresel sermaye piyasaları üzerindeki etkisini olay çalışması yöntemi ile incelemişlerdir. Çalışmada, terörün ABD sermaye piyasaları üzerindeki etkisini görmek amacıyla 1915 yılından itibaren 11 Eylül 2001 saldırısını da içerecek şekilde meydana gelen 14 terör olayının Dow Jones Endüstriyel Ortalama Endeksi üzerindeki etkisi analiz edilmiştir. Gerçekleşen 14 terör olayından 12'sinin getirileri negatif olarak etkilediği, bununla birlikte 19 Nisan 1995 yılında Alfred P. Murrah Federal Binasının ve 7 Ağustos 1998 yılında Kenya'daki ABD elçilik binalarının bombalanması olaylarının ise getiriler üzerinde pozitif etkisi olduğu görülmüştür. Daha sonra 11 Eylül saldırılarının ve Irak'ın Kuveyt'e saldırısının küresel sermaye piyasaları üzerindeki etkisini incelemişlerdir. 11 Eylül saldırısının etkisini görmek amacıyla Dünya genelindeki 33 sermaye piyasası ele alınmış ve 11 Eylül saldırısının bu piyasaları negatif etkilediği görülmüştür. Irak'ın Kuveyt'e saldırısının etkisini görmek amacıyla ise 18 sermaye piyasası dikkate alınmış ve bunlardan 17'si üzerinde 11 Eylül saldırısının negatif etkisi olduğu saptanmıştır. En yüksek negatif getirilerin Asya ve Avrupa'da gerçekleştiği, ABD piyasasındaki düşüşün ise diğer sermaye piyasaları kadar çok olmadığı görülmüştür.

Arin vd. (2008), çalışmalarında 2002-2006 dönemi için Endonezya, İsrail, İspanya, Tayland, Türkiye ve İngiltere ülkelerinde terör olaylarının hisse senedi piyasası üzerindeki etkisini incelemişlerdir. Yurtiçi faiz oranı (90 günlük hazine bonosu) ve küresel hisse senedi piyasası endeks değerleri değişken olarak kullanılmıştır. Terör endeksi insan kayıpları, yaralı insan sayısı ve terörist saldırı sayılarının toplamından oluşan günlük olayların doğal logaritması alınarak tanımlanmıştır. Çok değişkenli GARCH yönteminin uygulandığı çalışmada ülkelere ait terör olaylarının sayısı ve borsa endeksleri kullanılmıştır. Çalışmanın sonucunda terörün hisse senedi piyasaları ve oynaklığı üzerinde anlamlı bir etkiye sahip olduğu ve bu etkilerin büyüklüğünün gelişmekte olan piyasalarda daha büyük olduğu tespit edilmiştir.

Mutan ve Topçu (2009), çalışmalarında 1990-2009 dönemi için gerek Türkiye gerekse dünyada meydana gelen ekonomik, politik, çevresel, askeri ve terör olaylarının Türk hisse senedi piyasası üzerindeki etkisini incelemişlerdir. Bu amaçla BIST 100 endeks getiri verileri kullanılmış ve Brown ile Warner (1985)'ın olay çalışması yönteminden yararlanılmıştır. Çalışma sonucunda beklenmedik olayların borsayı olumsuz yönde etkilediği gözlenmiştir.

Christofis vd. (2010), 1997-2009 dönemi için Türkiye'de terör olaylarının BIST 100 endeksi üzerindeki etkisini olay çalışması yöntemiyle ele almıştır. Terör saldırılarının meydana geldiği günlerin kukla değişken olarak ele alındığı bu çalışmada, terör saldırılarının borsa üzerindeki negatif etkilerinin yüksek olduğu ve ayrıca büyüme ile artan güven nedeniyle kısa sürdüğü sonuçlarına ulaşılmıştır.

Drakos (2010), 1994-2004 dönemi için 22 ülkede terörist saldırıların ülke borsa endeksleri üzerindeki etkilerini Brezilya, Kolombiya, Mısır, Fransa, Almanya, Yunanistan, 
Hindistan, Endonezya, İsrail, Lübnan, Meksika, Pakistan, Peru, Filipinler, Rusya, İspanya, Sri Lanka, Tayland, Türkiye, İngiltere, Amerika ve Venezuela ülkeleri için incelemiş ve çalışmada bu ülkelere ait borsa günlük kapanış verilerini kullanmıştır. Çalışmada havuzlanmış panel ARCH modellerinden yararlanılmış ve analizler sonucunda terörist faaliyetlerin hisse senedi getirilerinin azalmasına neden olduğu belirlenmiştir.

Chesney vd. (2011), çalışmalarında 1994-2005 dönemi için Pakistan'da terör olaylarının hisse senedi, tahvil, altın ve emtia piyasaları üzerindeki etkilerini ele almışlardır. Çalışmada olay çalışması, parametrik olmayan istatistik ve GARCH-EVT yöntemleri uygulanmıştır. Sonuç olarak terör olaylarının altın piyasası üzerindeki etkisinin daha uzun sürdüğü gözlenmiştir.

Kollias vd. (2011), 2003-2005 dönemi için çalışmalarında 2004 Madrid ve 2005 Londra saldırılarının İspanya ve İngiltere Borsaları üzerindeki etkilerini araştırmışlardır. Çalışmada İspanya'da üç büyük borsanın ve İngiltere Borsası'nın günlük kapanış verileri kullanılmış, olay çalışması ile GARCH modellerinden yararlanılmıştır. Çalışma sonucunda İspanya piyasasının terörist saldırılardan negatif olarak etkilendiği görülmüştür. Ayrıca, İngiltere hisse senedi piyasasının tepkisinin İspanya piyasasına göre çok daha hılı olduğu gözlenmiştir. Bununla birlikte terörün hisse senedi getirileri ve oynaklığı üzerindeki etkisinin uzun süre devam etmediği tespit edilmiştir.

Bilal vd. (2012), 2005-2010 dönemi için Pakistan'da terör olaylarının etkisini GARCH, GARCH-EVT ve eşbütünleşme yöntemleriyle incelemişlerdir. Çalışmada faiz oranı, enflasyon oranı, terör ve Karachi Borsası (KSE) endeksleri kullanılmıştır. Analiz sonucunda terör olayları ile faiz oranının borsa endeksi üzerinde etkili olduğu ancak enflasyon oranının borsa endeksi üzerinde anlamlı bir etkiye sahip olmadığı belirlenmiştir.

Aurangzeb ve Dilawer (2012), 2004-2010 dönemi için Pakistan'da terör olayları ile borsa endeks değeri arasındaki ilişkiyi inceledikleri çalışmalarında regresyon ve Granger nedensellik analizlerinden yararlanmışlardır. Çalışmada Karachi 30 endeksinde yer alan 30 şirketin borsa getirileri ile suikast, bombalama, rehin alma ve altyapı saldırıları değişkenleri kullanılmıştır. Çalışmanın sonucunda, borsa getirilerinin terör olaylarından negatif yönde etkilendiği gözlenmiştir.

Graham ve Ramiah (2012), çalışmalarında 1999-2007 dönemi için New York Dünya Ticaret Merkezi, Bali, Madrid, Londra ve Mumbai'de meydana gelen terör olaylarının Japonya endüstrisi üzerindeki etkisini olay çalışması yöntemiyle incelemişlerdir. Günlük borsa endeksleri, Japonya' daki 3 aylık hazine bonosu ve ABD ile Avrupa için 10 yıllık tahvil getirisi değişkenleri kullanılmıştır. Çalışmada, 11 Eylül olaylarının Japon piyasaları üzerinde etkili olduğu saptanmıştır. Endüstrilerin çoğunluğunun terör olayından sonraki ilk işlem gününde aşağı yönlü olduğu ve endüstrilerin yarısının olaydan sonraki 5 gün negatif olarak etkilendiği belirlenmiştir. Çalışmada New York'ta ikiz kulelere yapılan saldırıların hem kısa hem de uzun dönemde sektörlerin sistematik riskinin arttığı gözlenmiştir. Bununla birlikte, Japonya'daki sektörlerin Mumbai'deki ve Londra'daki saldırılara duyarsız olduğu görülmüştür. 
Essaddam ve Karagianis (2014), 1995-2010 dönemini dikkate aldıkları çalışmalarında Amerika'da terörün hisse senedi getirilerini nasıl etkilediğini ortaya koymaya çalışmışlardır. Çalışmada sadece firmaları hedef alan dinsel, politik, ekonomik, çevresel ve bilinmeyen olarak nitelendirilen terör olayları dikkate alınmış ve olay çalışması yönteminden yararlanılmıştır. Çalışmanın sonucunda, terörün borsa getirilerinin oynaklığını açıklamada önemli bir faktör olduğu tespit edilmiştir. Ayrıca terörist saldırıların firmaların getiri oynaklıkları üzerindeki etkilerinin, olayın gerçekleştiği ülkenin özelliklerine göre farklılaştığ 1 gözlenmiştir. Daha demokratik veya zengin ülkelerde faaliyet gösteren firmalara yapılan saldırıların daha yüksek oynaklığa neden olduğu ve gelişmekte olan ülkelerde terörist saldırıların belirsizliği arttırmadığı belirlenmiştir.

Ağırman vd. (2014), çalışmalarında 2003-2011 dönemi için 35 ülkede terörün borsa endeksi üzerindeki etkisini Pedroni ve Kao eşbütünleşme yöntemiyle incelemişlerdir. Çalışmada değişken olarak küresel terörizm ile yıllık ortalama borsa endeksleri kullanılmıştır. Çalışmanın sonucunda, terör olaylarının hisse senedi piyasaları üzerinde kısa dönemdeki negatif etkisinin uzun dönemde piyasa mekanizmasıyla düzeltildiği tespit edilmiştir.

Çalışmanın bu kısmında finansal piyasalar ile ilgili literatür özetlenmek istenmiştir ve ilgili literatür özeti Tablo 3 'te sunulmuştur.

Tablo: 3

Terörün Finansal Piyasalar Üzerine Etkilerini İnceleyen Çalışmaların Özeti

\begin{tabular}{|c|c|c|c|}
\hline Yazar & Dönem-Ülke-Yöntem & Değişkenler & Sonuç \\
\hline $\begin{array}{l}\text { Chen and } \\
\text { Siems } \\
(2004)\end{array}$ & $\begin{array}{l}\text { 1915-2001; ABD, Asya ve } \\
\text { Avrupa'daki } 33 \text { hisse senedi } \\
\text { piyasası } \\
\text { Olay çalışması }\end{array}$ & $\begin{array}{l}\text { Dow Jones } \\
\text { Endeksi, ralama } \\
\text { sermayeresel } \\
\text { terör olayları }\end{array}$ & $\begin{array}{l}\text { Terör olayları hisse senedi piyasalarını } \\
\text { negatif olarak etkilemektedir. En } \\
\text { yüksek negatif getirilerin Asya ve } \\
\text { Avrupa'da gerçekleştiği, ABD } \\
\text { piyasasının diğer sermaye piyasaları } \\
\text { kadar sert düşmediği görülmüştur. }\end{array}$ \\
\hline $\begin{array}{l}\text { Arin vd. } \\
(2008)\end{array}$ & $\begin{array}{l}\text { 2002-2006; Endonezya, İsrail, } \\
\text { İspanya, Tayland, Türkiye ve } \\
\text { İngiltere; } \\
\text { Çok değişkenli GARCH }\end{array}$ & $\begin{array}{l}\text { Terör olayları sayısı, } \\
\text { borsa endeksi }\end{array}$ & $\begin{array}{l}\text { Terör olayları hisse senedi piyasalarını } \\
\text { olumsuz etkilemektedir. }\end{array}$ \\
\hline $\begin{array}{l}\text { Mutan ve } \\
\text { Topçu } \\
\text { (2009) }\end{array}$ & $\begin{array}{l}\text { 1990-2009; Türkiye; } \\
\text { Olay çalışması }\end{array}$ & \begin{tabular}{|lrr} 
Türkiye'de & ve \\
dünyada & meydana \\
gelen & ekonomik, \\
politik, & \multicolumn{2}{r}{ çevresel, } \\
askeri & ve & terör \\
olaylarl, & BIST & 100 \\
endeks & getirileri & \\
\end{tabular} & 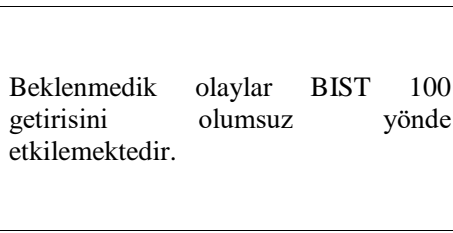 \\
\hline $\begin{array}{l}\text { Christofis } \\
\text { vd. (2010) }\end{array}$ & $\begin{array}{l}\text { 1997-2009; Türkiye; Olay } \\
\text { çalışması }\end{array}$ & $\begin{array}{l}\text { BIST } 100 \\
\text { Terör günleri }\end{array}$ & $\begin{array}{l}\text { Terörist saldırılar hisse senetlerini } \\
\text { negatif etkilemektedir, ancak yüksek } \\
\text { büyüme ve artan güven sayesinde bu } \\
\text { etki kısa sürmektedir. }\end{array}$ \\
\hline $\begin{array}{l}\text { Drakos } \\
(2010)\end{array}$ & $\begin{array}{l}\text { 1994-2004; } r \text { Brezilya, } \\
\text { Kolombiya, Misir, Fransa, } \\
\text { Almanya, } \\
\text { Hindistan, Endonezya, İsrail, } \\
\text { Lübnan, Meksika, Pakistan, }\end{array}$ & $\begin{array}{l}\text { Borsa günlük kapanış } \\
\text { verileri }\end{array}$ & $\begin{array}{llcc}\text { Terörist } & \text { faaliyetler } & \text { hisse } & \text { senedi } \\
\text { getirileri } & \text { üzerinde } & \text { negatif } & \text { etkiye } \\
\text { sahiptir. } & & & \end{array}$ \\
\hline
\end{tabular}




\begin{tabular}{|c|c|c|c|}
\hline & $\begin{array}{l}\text { Peru, Filipinler, Rusya, İspanya, } \\
\text { Sri Lanka, Tayland, Türkiye, } \\
\text { İngiltere, Amerika ve } \\
\text { Venezuela; } \\
\text { Havuzlanmıș Panel ARCH }\end{array}$ & & \\
\hline $\begin{array}{l}\text { Chesney vd. } \\
(2011)\end{array}$ & $\begin{array}{l}\text { 1994-2005Pakistan; } \\
\text { Olay çalışması, Parametrik } \\
\text { olmayan istatistik, GARCH- } \\
\text { EVT }\end{array}$ & $\begin{array}{l}\text { Terör olayları sayısı, } \\
\text { hisse senedi, tahvil } \\
\text { altın, emtia piyasası }\end{array}$ & $\begin{array}{l}\text { Terörist saldırılar finansal piyasaları } \\
\text { negatif olarak etkilemektedir, riskten } \\
\text { korunmak için portföy çeşitlendirmesi } \\
\text { yapılmalıdır. }\end{array}$ \\
\hline $\begin{array}{l}\text { Kollias } \\
\text { vd.(2011) }\end{array}$ & $\begin{array}{l}\text { 2003-2005; İspanya ve İngiltere; } \\
\text { Olay çalışmasi, GARCH } \\
\text { modelleri }\end{array}$ & $\begin{array}{l}2004 \text { Madrid ve } 2005 \\
\text { Londra saldırıları, } \\
\text { hisse senedi piyasası } \\
\text { günlük } \\
\text { serileri }\end{array}$ & 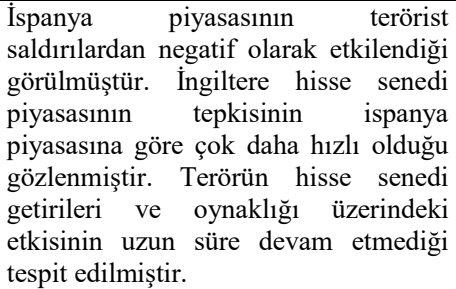 \\
\hline $\begin{array}{l}\text { Bilal vd. } \\
(2012)\end{array}$ & $\begin{array}{l}\text { 2005-2010; Pakistan; } \\
\text { GARCH, GARCH-EVT ve } \\
\text { eşbütünleşme }\end{array}$ & $\begin{array}{l}\text { Faiz oran1, enflasyon } \\
\text { oran1, KSE 100, terör } \\
\text { olayları }\end{array}$ & $\begin{array}{l}\text { Terör olayları ve faiz oranı KSE100 } \\
\text { negatif etkilemektedir. Enflasyon oranı } \\
\text { anlamlı bir etkiye sahip değildir. }\end{array}$ \\
\hline $\begin{array}{l}\text { Aurangzeb } \\
\text { and Dilawer } \\
(2012)\end{array}$ & $\begin{array}{l}\text { 2004-2010; Pakistan; } \\
\text { Regresyon analizi, Granger } \\
\text { nedensellik }\end{array}$ & $\begin{array}{l}\text { KSE } 30 \text { endeksi, terör } \\
\text { olayları }\end{array}$ & $\begin{array}{l}\text { Borsa getirileri terör olaylarından } \\
\text { negatif etkilenmektedir. }\end{array}$ \\
\hline $\begin{array}{l}\text { Graham ve } \\
\text { Ramiah } \\
\text { (2012) }\end{array}$ & $\begin{array}{l}\text { 1999-2007; Japonya; Olay } \\
\text { çalışması }\end{array}$ & $\begin{array}{l}\text { Günlük borsa } \\
\text { endeksleri, } \\
\text { Japonya'daki } 3 \text { aylık } \\
\text { hazine bonosu ve } \\
\text { ABD ile Avrupa için } \\
10 \text { yıllık tahvil }\end{array}$ & $\begin{array}{l}\text { New York'da ikiz kulelere yapılan } \\
\text { saldırıların hem kısa hem de uzun } \\
\text { dönemde sektörlerin sistematik riskinin } \\
\text { arttığı gösterilmiştir. Bununla birlikte, } \\
\text { Japonya'daki sektörlerin Mumbai ve } \\
\text { Londra'daki saldırılara duyarsız } \\
\text { olduğunu bulmuşlardır. }\end{array}$ \\
\hline $\begin{array}{l}\text { Essaddam } \\
\text { ve } \\
\text { Karagianis } \\
(2014)\end{array}$ & $\begin{array}{l}\text { 1995-2010; Amerika } \\
\text { Olay çalışması }\end{array}$ & $\begin{array}{l}\text { Amerika'da } \\
\text { faaliyetlerde bulunan } \\
\text { firmalara ait getiriler }\end{array}$ & $\begin{array}{l}\text { Terör borsa getirilerinin oynaklığını } \\
\text { açıklamada önemli bir faktördür. }\end{array}$ \\
\hline $\begin{array}{l}\text { Ağırman vd. } \\
(2014)\end{array}$ & $\begin{array}{l}\text { 2003-2011; } 35 \text { ülke; Panel } \\
\text { Pedroni, Kao eşbütünleşme, }\end{array}$ & $\begin{array}{lr}\begin{array}{l}\text { Ülkelere ait } \\
\text { endeksleri, }\end{array} & \text { borsa } \\
\text { olayları } & \text { terör } \\
\end{array}$ & $\begin{array}{l}\text { Borsa endeksi ile terör olayları arasında } \\
\text { uzun dönemli ilişki ve çift yönlü } \\
\text { nedensellik vardır. } \\
\text { Terörist saldırıların kısa dönemde borsa } \\
\text { üzerindeki negatif etkisi uzun dönemde } \\
\text { ortadan kalkmaktadır. }\end{array}$ \\
\hline
\end{tabular}

Literatür incelendiğinde terörist faaliyetlerin finansal piyasalar üzerine etkilerinin kısa dönemde olumsuz bir etki yarattığı (Aurangzeb \& Dilawer, 2012: 73), benzer şekilde altın piyasasının terörist olaylara karşı tepkisinin negatif olduğu görülmektedir. Emtia piyasası açısından ele alındığında ise, terör olaylarının altın piyasası üzerindeki negatif etkisinin daha uzun sürdüğü görülmektedir (Chesney vd., 2011: 254). Dolayısıla literatürden hareketle, terörizmin finansal piyasalar üzerinde genellikle negatif bir etkisinin olduğu söylenebilmektedir. Türkiye için terör olaylarının hisse senedi piyasası üzerindeki etkisinin araştırıldığı çalışmalar incelendiğinde de bu durum geçerli olmakla beraber bu etkinin geçici olduğu söylenebilmektedir. Bununla birlikte literatürde, terör olaylarının finansal piyasalar üzerindeki etkisini alt sektörler bazında inceleyen herhangi bir çalışmaya 
rastlanılmamıştır. Çalışmanın alt sektörler bazında terör olaylarının finansal piyasaları incelemesi yönüyle özgün bir nitelik taşıdığı ve bu açıdan literatüre katkı yapacağı düşünülmektedir.

\section{Veri Seti}

Bu çalışmanın amacı Türkiye' de meydana gelen terör olaylarının altın ve hisse senedi piyasası ile alt sektör getirileri ve oynaklığı üzerindeki etkisini analiz etmektir. Bu nedenle, 02 Ocak 2009-31 Aralık 2014 dönemi için günlük kapanış fiyatlarına göre altın piyasası endeksi ile BIST 100 endeksi ve hizmet, mali, sınai ve teknoloji alt sektör kapanış endeks değerleri kullanılmıştır. Çalışmada kullanılan finansal değişkenler TCMB elektronik veri dağıtım sistemin (EVDS)'den, terör olayları ise Global Terrorism veri tabanından elde edilmiştir.

Çalışmada ilk olarak kullanılacak değişkenlere ilişkin getiri serileri elde edilmek istenmektedir. $\mathrm{Bu}$ amaçla günlük getiri serileri her bir değişken için aşağıdaki gibi oluşturulmuştur:

$$
R_{t}=\ln \left(P_{t} / P_{t-1}\right)
$$

Burada $R_{t}$, her bir seri için t zamanındaki getiriyi ve $P_{t}$, t zamanındaki endekslerin kapanış değerlerini göstermektedir. Çalışmada değişkenlere ait bilgiler Tablo 4'te gösterilmiştir ve getiri serileri değişkenlerin önüne " $R$ " harfi eklenerek ifade edilmiştir.

Tablo: 4

\section{Çalışmada Kullanılan Değişkenler}

\begin{tabular}{|c|c|c|c|}
\hline Değișkenin Adı & Açıklaması & Değișkenin Adı & Açıklaması \\
\hline Gold & Altın piyasası kapanış endeksi & Industrial & Sınai alt sektör kapanış endeksi \\
\hline Bist & Borsa İstanbul 100 kapanış endeksi & Service & Hizmet alt sektör kapanış endeksi \\
\hline Financial & Finansal alt sektör kapanış endeksi & Technology & Teknoloji alt sektör kapanış endeksi \\
\hline Rgold & $\ln \left(\right.$ Gold $_{t} /$ Gold $\left._{t-1}\right)$ & Rindustrial & $\ln \left(\right.$ Industrial $_{\mathrm{t}} /$ Industrial $_{\mathrm{t}-1}$ ) \\
\hline Rbist & $\ln \left(\right.$ Bist $_{t} /$ Bist $\left._{t-1}\right)$ & Rservice & $\ln \left(\right.$ Service $_{t} /$ Service $\left._{t-1}\right)$ \\
\hline Rfinancial & $\ln \left(\right.$ Financial $_{\mathrm{t}} /$ Financial $\left._{\mathrm{t}-1}\right)$ & Rtechnology & $\ln \left(\right.$ Techonolgy $\mathrm{y}_{\mathrm{t}} /$ Technology $\left._{\mathrm{t}-1}\right)$ \\
\hline
\end{tabular}

Şekil 1'de Gold, Bist, Financial, Industrial, Service ve Technology değişkenleri için 02 Ocak 2009-31 Aralık 2014 döneminde izledikleri seyire ilişkin zaman yolu grafikleri yer almaktadir. 
Şekil: 1

Altın Piyasası Endeksi, BIST 100 ve Diğer Alt Sektör Endekslerine İlişkin Zaman Yolu Grafikleri

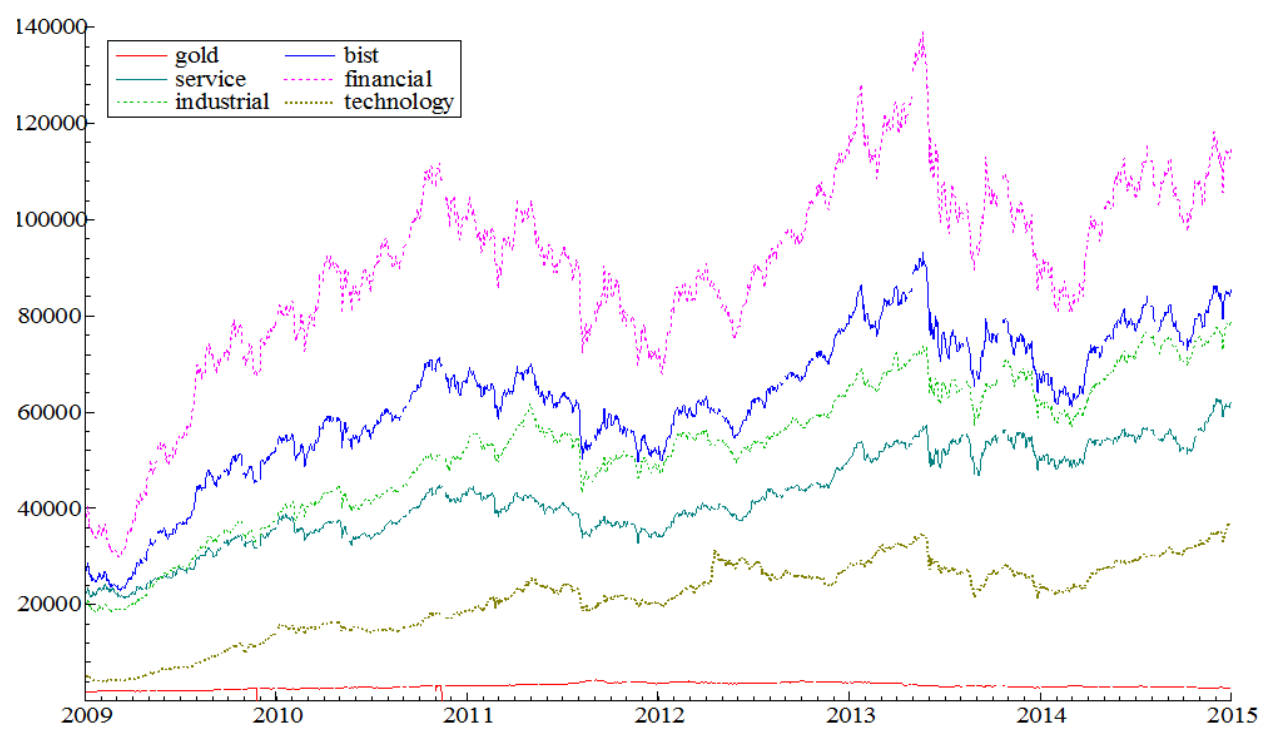

Kaynak: Yazarlar tarafindan Oxmetrics programı kullanılarak oluşturulmuştur.

\section{Metodoloji}

Finansal zaman serilerinin varyansı zaman içinde değiş̧kenlik göstermektedir. Bu nedenle finansal zaman serilerinin modellenmesinde koşullu varyans modelleri kullanılmaktadır. Oynaklık modellenmesi ile ilgili sistematik bir çerçeve sağlayan ilk model Engle (1982) 'in ARCH modelidir. ARCH regresyon modeli, $Y_{t}$ 'nin ortalamasının $X_{t} \beta$ olduğu varsayılarak elde edilebilir. Burada $X_{t} \beta, \beta$ bilinmeyen parametre vektörü ile $\psi_{t-1}$ bilgi setine dahil olan dişsal değişkenler ile gecikmeli içsel değişkenin doğrusal kombinasyonudur. $e_{t}$ hata terimini, $h_{t}^{2}$ koşullu varyansı, $h_{t}$ koşullu standart sapmayı ifade etmektedir. (Engle, 1982: 986-989).

$$
h_{t}^{2}=\alpha_{0}+\sum_{i=1}^{p} \alpha_{i} e_{t-i}^{2}
$$

Burada $Y_{t} / \psi_{t-1} \sim N\left(X_{t} \beta, h_{t}\right), \quad h_{t}=f\left(e_{t-1}, e_{t-2}, \ldots, e_{t-p}, \alpha\right) \quad e_{t}=Y_{t}-X_{t} \beta$ 'dir. $\alpha_{0}>0$ ve $\alpha_{i} \geq 0, i=1, \ldots, p-1$ ve aynı zamanda $\alpha_{p}>0$. Bu şartlar koşullu varyansın her zaman pozitif olmasını sağlamaktadır (Kirchgassner, Wolters, 2007: 245-246). 
Bir diğer koşullu değişen varyans modeli ise GARCH modelidir. GARCH modeli Bollerslev (1986) tarafından ortaya atılmıştır. $\psi_{t} \mathrm{t}$ zamanındaki bilgi setini göstermektedir. $\operatorname{GARCH}(p, q)$ süreci aşağıdaki gibi ifade edilmektedir:

$$
h_{t}^{2}=\alpha_{0}+\sum_{i=1}^{q} \alpha_{i} e_{t-i}^{2}+\sum_{i=1}^{p} \beta_{i} h_{t-i}^{2}=\alpha_{0}+A(L) e_{t}^{2}+B(L) h_{t}^{2}
$$

Burada, $e_{t} / \Psi_{t-1} \sim N\left(0, h_{t}\right), \quad p \geq 0, q>0 \quad, \quad \alpha_{0}>0, \alpha_{i} \geq 0, i=1, \ldots, q \quad, \beta_{i} \geq$ $0 \mathrm{i}=1,2, \ldots, \mathrm{p}$ 'dir. $p=0$ için, süreç ARCH(q) sürecine indirgenir, ve $p=q=0$ için $e_{t}$ beyaz gürültülüdür (Bollerslev, 1986: 308-309). GARCH(p,q) sürecinin varyansının var olması için $\alpha(1)+\beta(1)=\sum_{i=1}^{p} \alpha_{i}+\sum_{i=1}^{q} \beta_{i}<1$ olmas1 gerekmektedir (Kirchgassner, Wolters, 2007: $252-254)$.

EGARCH modeli Nelson (1991) tarafından geliştirilmiştir. Koşullu varyans $h_{t}^{2}$ pozitif olmak zorundadır. ARCH modeli, bunu $h^{2}$ 'yi pozitif rassal değişkenlerin doğrusal bir kombinasyonu şeklinde ifade ederek sağlamaktadır. $h^{2}$ 'nin pozitif olmasını sağlamak için diğer bir yöntem, gecikmeli $z_{t}$ ve zamanın bir fonksiyonu olarak $\ln \left(h_{t}^{2}\right)$ 'yi doğrusallaştırmaktır.

$$
\ln \left(h_{t}^{2}\right)=\alpha_{t}+\sum_{k=1}^{\infty} \beta_{k} g\left(z_{t-k}\right), \beta_{1} \equiv 1
$$

Burada $z_{t}$ standartlaştırılmış artıktır. EGARCH modeli borsa getirileri ve oynaklık değişimleri arasındaki asimetrik ilişkiyi ortaya koymaktadır. Bunu sağlamak için, $g\left(z_{t}\right)$ 'nin değeri $z_{t}$ 'nin işaretinin ve büyüklüğünün bir fonksiyonu olması gerekmektedir. $g\left(z_{t}\right)$, şartlı varyans sürecinin $\left\{h_{t}^{2}\right\}$ hisse senedi fiyatlarındaki artış ve azalışlara asimetrik tepki verilmesine izin vermektedir (Nelson, 1991: 350-351). $\operatorname{EGARCH}(p, q)$ modeli aşağıdaki gibi ifade edilmektedir:

$$
\begin{aligned}
& \ln h_{t}^{2}=\alpha_{0}\left(1-\beta_{1}\right)+\gamma_{1} \frac{u_{t-1}}{\sqrt{h_{t-1}^{2}}}+\gamma_{2}\left(\left|\frac{u_{t-1}}{\sqrt{h_{t-1}^{2}}}\right|-E\left|\frac{u_{t-1}}{\sqrt{h_{t-1}^{2}}}\right|\right)+\beta_{1} \ln h_{t-1}^{2} \\
& \ln h_{t}^{2}=w_{t}+\sum_{T=1}^{p} \alpha_{i} g\left(z_{t-i}\right)+\sum_{T=1}^{q} \gamma_{j} \ln \left(h_{t-j}^{2}\right) \\
& g\left(z_{t}\right)=\theta z_{t}+\gamma\left[\left|z_{t}\right|-E\left|z_{t}\right|\right] \\
& z_{t}=\frac{u_{t}}{\sqrt{h_{t}^{2}}}
\end{aligned}
$$

GJR - GARCH modeli Glosten vd. (1993) tarafından ortaya çıkarılmıştır. Pozitif ve negatif beklenmeyen getiriler şartlı varyans üzerinde farklı etkilere sahiptir. Aynı zamanda, borsa getirilerinin şartlı ortalama ve şartlı varyansı arasında negatif bir ilişki vardır (Glosten vd. 1993: 1799). 


$$
h_{t}^{2}=\omega+\sum_{i=1}^{q} \alpha_{i} e_{t-i}^{2}+\sum_{i=1}^{r} \gamma_{k} e_{t-i}^{2} d_{t-i}+\sum_{j=1}^{p} \beta_{j} h_{t-j}^{2}
$$

Yukarıdaki varyans denkleminde yer alan kukla değişken $\left(d_{t}\right), e_{t-i}<0$ değerini aldığında $d_{t}=1$, diğer durumlarda ise $d_{t}=0$ değerini almaktadır. Bu nedenle asimetri parametresi $\gamma, d_{t}=1$ değerini aldığında anlamlı olmaktadır.

\section{Bulgular}

Çalışmada ilk olarak getiri serilerine ilişkin tanımlayıcı istatistiklere yer verilmiş ve elde edilen sonuçlar Tablo 5'te gösterilmiştir.

Tablo: 5

\section{Tanımlayıcı İstatistikler}

\begin{tabular}{|c|c|c|c|c|c|c|}
\hline & Rgold & Rbist & Rservice & Rfinancial & Rindustrial & Rtechnology \\
\hline Ortalama & 0.0001 & 0.0006 & 0.0006 & 0.0006 & 0.0008 & 0.0012 \\
\hline Medyan & 0.0004 & 0.0012 & 0.0009 & 0.0009 & 0.0014 & 0.0016 \\
\hline Maksimum & 0.4345 & 0.0689 & 0.0620 & 0.0771 & 0.0645 & 0.0912 \\
\hline Minimum & -0.4116 & -0.1106 & -0.0969 & -0.1129 & -0.1140 & -0.1292 \\
\hline Std. Sapma & 0.0194 & 0.0155 & 0.0128 & 0.0185 & 0.0128 & 0.0173 \\
\hline Çarpıklık & 1.0911 & -0.4526 & -0.5080 & -0.2611 & -1.1786 & -0.4520 \\
\hline Basıklık & 310.55 & 6.5204 & 7.2473 & 5.2865 & 12.28721 & 8.0831 \\
\hline Jarque-Bera & 57664 & 805.46 & 1162.61 & 335.33 & 5596.524 & 1624.88 \\
\hline Olasıllık Değeri & $0.0000^{* * *}$ & $0.0000^{* * *}$ & $0.0000^{* * *}$ & $0.0000^{* * *}$ & $0.0000^{* * *}$ & $0.0000^{* * *}$ \\
\hline Gözlem & 1564 & 1564 & 1564 & 1564 & 1564 & 1564 \\
\hline
\end{tabular}

Tablo 5'te Rgold, Rbist, Rservice, Rfinancial, Rindustrial ve Rtechnology değişkenleri sırasıyla altın piyasası endeksi, BIST 100 endeksi ile hizmet, mali, sınai ve teknoloji alt sektör endeks getirilerini ifade etmektedir. Altın piyasası endeks getirisinin ortalama değeri 0.0001 ve medyanı 0.0004 'tür. Standart sapma değeri \%1.94'tür. Bu değer ortalama getiri ile karşılaştırıldığında oldukça yüksektir ve getirilerin sıklıkla ortalamadan saptığını göstermektedir. Çarpıklık değeri pozitiftir ve getiriler eğrinin sağ tarafında yoğunlaşmıştır. Basıklık değeri 310.55 ile oldukça yüksek bir değere sahiptir. Bu nedenle değişkenler normal dağılım özelliği göstermeyip leptokurtic dağılıma sahiptir.

BIST 100 endeks getirisinin ortalama değeri 0.0006 ve medyanı 0.0012 'dir. Standart sapma değeri \%1.5546'dır. Bu değer ortalama getiri ile karşılaştırıldığında oldukça yüksektir ve getirilerin sıklıkla ortalamadan saptığını göstermektedir. Çarpıklık değeri negatiftir ve getiriler eğrinin sol tarafinda yoğunlaşmıştır. Basıklık değeri 6.5204'tür ve bu değer normal dağılımı ifade eden "3" kritik değerinden yüksektir. Bu nedenle BIST 100 getiri serisi leptokurtic dağılım özelliğine sahiptir. Hizmet, mali, sınai ve teknoloji alt sektör getirilerine ilişkin tanımlayıcı istatistikler incelendiğinde, tüm getirilerin pozitif olduğu görülmektedir. Alt sektörlere ilişkin getiri serilerinin tümü negatif çarpıklık değerlerine ve aşırı basıklık değerlerine sahiptir. Bu sonuç, oynaklık kümelemesi nedeniyle finansal getiri serilerinin leptokurtic dağılıma sahip olmasıyla açıklanabilir. 
Çalışmada analizin güvenilir sonuçlar verebilmesi için getiri serilerinin birim kök içerip içermediğinin araştırılması gerekmektedir. Bu amaçla, getiri serilerinin durağanlığı sabit terimli ADF birim kök testi aracılığıyla araştırılmıştır ve elde edilen birim kök testi sonuçları Tablo 6'da gösterilmektedir.

Tablo: 6

Sabit Terimli ADF Birim Kök Test Sonucu

\begin{tabular}{|c|c|c|c|c|}
\hline & \multirow{2}{*}{$\frac{\text { Birim Kök Testi }}{\text { ADF Test }}$} & \multicolumn{3}{|c|}{ Kritik Değerler } \\
\hline & & $\% 1$ & $\% 5$ & $\% 10$ \\
\hline Rgold & $-37.4988^{* * *}$ & -3.4343 & -2.8631 & -2.5676 \\
\hline Rbist & $-40.4651^{* * *}$ & -3.4343 & -2.8631 & -2.5676 \\
\hline Rservice & $-40.5299^{* * *}$ & -3.4343 & -2.8631 & -2.5676 \\
\hline Rfinancial & $-40.4437^{* * *}$ & -3.4343 & -2.8631 & -2.5676 \\
\hline Rindustrial & $-38.9066^{* * *}$ & -3.4343 & -2.8631 & -2.5676 \\
\hline Rtechnology & $-38.5521^{* * *}$ & -3.4343 & -2.8631 & -2.5676 \\
\hline
\end{tabular}

Tablo 6'dan hareketle, getiri serilerinin tümünün \%1 önem seviyesinde birim kök içermediği ve serilerin durağan olduğu söylenebilmektedir.

Getiri serilerinin durağanlıklarının araştırılmasından sonra, uygun ARMA(p,q) modellerinin belirlenmesi gerekmektedir. En uygun seçim, otokorelasyon ve kımi otokorelasyon fonksiyonlarının birlikte değerlendirilmesine Akaike (AIC) ve Schwarz (SIC) bilgi kriterlerine bağlıdır. $\mathrm{Bu}$ kriterlere göre belirlenen $\operatorname{ARMA}(\mathrm{p}, \mathrm{q})$ modellerine ilişkin bilgiler Tablo 7'de sunulmuştur.

Tablo: 7

ARMA Modelleri

\begin{tabular}{lllcc}
\hline & Bağımlı Değişken & ARMA(p,q) & Akaike Bilgi Kriteri & Schwartz Bilgi Kriteri \\
\hline MODEL 1 & Rgold & ARMA(1,2) & -5.209 & -5.2171 \\
MODEL 2 & Rbist & ARMA(4,2) & -5.5236 & -5.4995 \\
MODEL 3 & Rservice & ARMA(3,3) & -5.8893 & -5.8618 \\
MODEL 4 & Rfinancial & ARMA(2,2) & -5.1829 & -5.1657 \\
MODEL 5 & Rindustrial & ARMA(4,4) & -5.9086 & -5.8776 \\
MODEL 6 & Rtechnoogy & ARMA $(3,3)$ & -5.3009 & -5.2768 \\
\hline
\end{tabular}

Tüm getiri serilerine ilişkin istatistiksel açıdan en uygun ARMA modelleri seçildikten sonra, bu ARMA modellerine ait hata terimlerinde $\mathrm{ARCH}$ etkisinin olup olmadığı ARCH-LM testi ile araştırılmıştır. Eğer ARCH etkisi mevcutsa getiri serilerinin oynaklığı ARCH tipi modeller ile araştırıldığından dolayı modellerde ARCH etkisinin varlığ i incelenmiştir. Getiri serileri için oluşturulan $\operatorname{ARMA}(\mathrm{p}, \mathrm{q})$ modelleri için uygulanan ARCH-LM test sonuçları Tablo 8'de yer almaktadır. 
Tablo: 8

ARCH-LM Test Sonuçları

\begin{tabular}{lllllll}
\hline & MODEL1 & MODEL2 & MODEL3 & MODEL4 & MODEL5 & MODEL6 \\
\hline Bağımlı Değişken & Rgold & Rbist & Rservice & Rfinancial & Rindustrial & Rtechnology \\
\hline 1 Gecikme & $243.7810^{* * *}$ & $24.2880^{* * *}$ & $56.8463^{* * *}$ & $12.4962^{* * *}$ & $67.7258^{* * *}$ & $205.4712^{* * *}$ \\
2 Gecikme & $259.7800^{* * * *}$ & $36.7391^{* * *}$ & $58.9070^{* * *}$ & $32.8638^{* * *}$ & $68.5780^{* * *}$ & $205.6186^{* * *}$ \\
4 Gecikme & $261.3050^{* * * *}$ & $60.4361^{* * *}$ & $107.3493^{* * *}$ & $51.3514^{* * *}$ & $100.9454^{* * *}$ & $219.5628^{* * * *}$ \\
8 Gecikme & $260.6952^{* * *}$ & $69.6438^{* * *}$ & $110.1492^{* * *}$ & $61.9227^{* * *}$ & $112.1590^{* * *}$ & $222.2583^{* * *}$ \\
\hline${ }^{* * * *},{ }^{* *}$, ve $^{*}$ sirasılyla, \%1, \%5 ve \%10 önem seviyesinde istatistiksel anlamlllı̆ göstermektedir. & \\
\hline
\end{tabular}

Tablo 8'den görüldüğü üzere tüm getiri serileri için 1, 2, 4 ve 8 gecikmede hesaplanan test istatistiklerinin olasılık değeri \%1 önem seviyesinden küçüktür. Bu nedenle, tüm getiri serileri için hatalarda ARCH etkisinin var olduğu söylenebilmektedir. Getiri serileri için oluşturulan $\operatorname{ARMA}(p, q)$ modellerinde $\mathrm{ARCH}$ etkisinin varlığının bulunmasından dolayı modellemeye otoregresif koşullu değişen varyans modelleri (ARCH ailesi modelleri) ile devam edilmiştir. Katsayıların anlamlılığı, Akaike, Schwartz ve Hannan-Quinn bilgi kriterleri dikkate alındığında getiri serileri için en uygun modeller belirlenmiştir. Buna göre getiri serileri için oluşturulan otoregresif koşullu değişen varyans modelleri Tablo 9'da gösterilmiştir.

Türkiye'de meydana gelen terör saldırılarının altın piyasası ve borsa getirileri üzerindeki etkisini belirlemek amaciyla tahmin edilen ve Tablo 9'da gösterilen modeller incelendiğinde, terör olaylarının etkisini gösteren $\varphi_{1}$ katsayısı tüm getiri serileri için istatistiksel olarak anlamsız olduğu gözlenmiştir.

Altın piyasası endeks getiri serisi için tahmin edilen EGARCH(1,1) modeline göre, $\gamma_{1}$ katsayısı pozitiftir ve \%1 önem seviyesinde istatistiksel olarak anlamlıdır. Dolayısıyla, negatif haberler altın piyasası oynaklığı üzerinde pozitif haberlere göre daha etkilidir $\left(\gamma_{1}=\right.$ $0.1944>0)$. Ayrıca büyüklük etkisini gösteren $\gamma_{2}(0.9140)$ katsayısı da pozitiftir ve $\% 1$ önem seviyesinde istatistiksel olarak anlamlıdır. Hizmet, sınai ve teknoloji alt sektörleri için tahmin edilen EGARCH modellerinde ise işaret etkisini gösteren $\gamma_{1}$ katsayıları negatif olarak bulunmuştur. Bu nedenle, pozitif haberler negatif haberlere göre serilerin oynaklığ üzerinde daha fazla etkiye sahiptir. Büyüklük etkisini gösteren $\gamma_{2}$ her üç modelde de pozitif olarak elde edilmiştir. Dolayısıyla, gerçekleşen durumlar beklenen durumlardan daha iyidir. $\mathrm{Bu}$ durum insanların beklentilerinin gerçekleşmediğini göstermektedir.

BIST 100 endeks getirisi için tahmin edilen Model 2'ye ait ARMA(4,2)-GJR(1,1) model sonucu incelendiğinde, ARCH parametresi $\left(\alpha_{1}\right)$ ve GARCH parametresi $\left(\beta_{1}\right)$ ile asimetri etkisini gösteren $\delta_{1}$ parametresi \%5 önem seviyesinde istatistiksel olarak anlamlıdır. $\delta_{1}>0$ olduğu için modelde kaldıraç etkisi vardır ve negatif haberler oynaklık üzerinde pozitif haberlere göre daha etkilidir. Mali alt sektörü için de benzer yorumlar yapılabilir. Asimetri parametresi $\delta_{1}$ pozitif olduğu için kaldıraç etkisinden söz edilebilmektedir. 
Tablo: 9

Model Tahmin Sonuçları

\begin{tabular}{|c|c|c|c|c|c|c|}
\hline & MODEL1 & MODEL2 & MODEL3 & MODEL4 & MODEL5 & MODEL6 \\
\hline Bağımlı Değişken & Rgold & Rbist & Rservice & Rfinancial & Rindustrial & Rtechnology \\
\hline & EGARCH $(1,1)$ & $\operatorname{GJR}(1,1)$ & EGARCH $(1,1)$ & $\operatorname{GJR}(1,1)$ & EGARCH $(1,1)$ & EGARCH $(1,1)$ \\
\hline$\varphi_{0}$ & $\begin{array}{l}-0.0006^{* * *} \\
(6.7262 \mathrm{e}-005)\end{array}$ & $\begin{array}{l}0.0010^{* * * *} \\
(0.0003)\end{array}$ & $\begin{array}{l}0.0012^{* * *} \\
(0.0004)\end{array}$ & $\begin{array}{l}0.0009^{* *} \\
(0.0004)\end{array}$ & $\begin{array}{l}-0.0915^{* * *} \\
(0.0060)\end{array}$ & $\begin{array}{l}0.0014^{* * * *} \\
(0.0004)\end{array}$ \\
\hline$\varphi_{1}$ & $\begin{array}{l}-0.0008 \\
(0.0009)\end{array}$ & $\begin{array}{l}-0.0007 \\
(0.0008)\end{array}$ & $\begin{array}{l}-0.0011 \\
(0.0010)\end{array}$ & $\begin{array}{l}-0.0007 \\
(0.0 .001)\end{array}$ & $\begin{array}{l}-0.0005 \\
(0.0007)\end{array}$ & $\begin{array}{l}-0.0001 \\
(0.0010)\end{array}$ \\
\hline$\varphi_{2}$ & $\begin{array}{l}0.4409^{* * * *} \\
(0.0022)\end{array}$ & $\begin{array}{l}-0.2816^{* * *} \\
(0.0848)\end{array}$ & $\begin{array}{l}0.3022^{* * *} \\
(0.0900)\end{array}$ & $\begin{array}{l}0.4702^{* * * *} \\
(0.07839)\end{array}$ & $\begin{array}{l}0.1403^{* * *} \\
(0.0036)\end{array}$ & $\begin{array}{l}-0.0807^{* * *} \\
(0.0127)\end{array}$ \\
\hline$\varphi_{3}$ & - & $\begin{array}{l}0.3660^{* * * *} \\
(0.1684)\end{array}$ & $\begin{array}{l}0.2704^{* * *} \\
(0.0476)\end{array}$ & $\begin{array}{l}-0.8141^{* * *} \\
(0.2381)\end{array}$ & $\begin{array}{l}0.3005^{* * *} \\
(0.0022)\end{array}$ & $\begin{array}{l}-0.1747^{* * *} \\
(0.0122)\end{array}$ \\
\hline$\varphi_{4}$ & - & $\begin{array}{l}0.03438 \\
(0.0289)\end{array}$ & $\begin{array}{l}0.0324^{* * * *} \\
(0.0117)\end{array}$ & ( & $\begin{array}{l}0.2476^{* * * *} \\
(0.0030)\end{array}$ & $\begin{array}{l}0.3943^{* * *} \\
(0.0082)\end{array}$ \\
\hline$\varphi_{5}$ & - & $\begin{array}{l}-0.0006 \\
(0.0276)\end{array}$ & 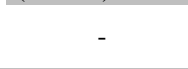 & - & $\begin{array}{l}0.31216^{* * *} \\
(0.0059)\end{array}$ & 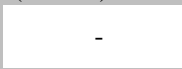 \\
\hline$\theta_{1}$ & $\begin{array}{l}-0.7720^{* * *} \\
(0.0011)\end{array}$ & $\begin{array}{l}0.2837^{* * *} \\
(0.0922)\end{array}$ & $\begin{array}{l}-0.2879^{* * *} \\
(0.0742)\end{array}$ & $\begin{array}{l}-0.4727^{* * *} \\
(0.0827)\end{array}$ & $\begin{array}{l}-0.1172^{* * *} \\
(0.0082)\end{array}$ & $\begin{array}{l}0.1155^{* *} \\
(0.0140)\end{array}$ \\
\hline$\theta_{2}$ & $\begin{array}{l}0.2571^{\text {*** }} \\
(0.0030)\end{array}$ & $\begin{array}{l}-0.3363^{* *} \\
(0.1709)\end{array}$ & $\begin{array}{l}-0.2667 \\
(0.0076)\end{array}$ & $\begin{array}{l}0.8335^{* * *} \\
(23572)\end{array}$ & $\begin{array}{l}-0.2943^{* * *} \\
(0.0025)\end{array}$ & $\begin{array}{l}0.15296^{* * *} \\
(0.0042)\end{array}$ \\
\hline$\theta_{3}$ & - & - & $\begin{array}{l}-0.3410^{* * *} \\
(0.1071)\end{array}$ & 18 & $\begin{array}{l}-0.2029^{* * *} \\
(0.0038)\end{array}$ & $\begin{array}{l}-0.4082^{* * *} \\
(0.0046)\end{array}$ \\
\hline$\theta_{4}$ & - & - & - & - & $\begin{array}{l}-0.2818^{* * *} \\
(0.0048)\end{array}$ & - \\
\hline$\omega$ & $\begin{array}{l}-270.9836 \\
(2143)\end{array}$ & $\begin{array}{l}0.1234^{* * *} \\
(0.0556)\end{array}$ & $\begin{array}{l}-195.4548^{* * *} \\
(1.3438)\end{array}$ & $\begin{array}{l}0.1224 \\
(0.0835)\end{array}$ & $\begin{array}{l}-200.9478 \\
(4292.800)\end{array}$ & $\begin{array}{l}-188.1622 \\
(3190.5)\end{array}$ \\
\hline$\alpha_{1}$ & $\begin{array}{l}0.3413^{* * *} \\
(0.1169)\end{array}$ & $\begin{array}{l}0.0413^{* * * *} \\
(0.0157)\end{array}$ & $\begin{array}{l}-0.2280^{* *} \\
(0.1140)\end{array}$ & $\begin{array}{l}0.03956^{* *} \\
(0.0176)\end{array}$ & $\begin{array}{l}-0.0904 \\
(0.1620)\end{array}$ & $\begin{array}{l}-0.31669^{* * *} \\
(0.08179)\end{array}$ \\
\hline$\beta_{1}$ & $\begin{array}{l}0.9763^{* * * *} \\
(0.0090)\end{array}$ & $\begin{array}{l}0.8515^{* * * *} \\
(0.0436)\end{array}$ & $\begin{array}{l}0.9967^{* * *} \\
(0.0010)\end{array}$ & $\begin{array}{l}0.8919^{* * * *} \\
(0.8919)\end{array}$ & $\begin{array}{l}0.9959^{* * * *} \\
(0.0013)\end{array}$ & $\begin{array}{l}0.9952^{* * * *} \\
(0.0010)\end{array}$ \\
\hline$\gamma_{2}$ & $\begin{array}{l}0.1944^{\text {**** }} \\
(0.0383) \\
0.9140^{* * *} \\
(0.1697)\end{array}$ & (1) & $\begin{array}{l}-0.0927^{* *} \\
(00.0368) \\
0.4546^{* * *} \\
(0.0649)\end{array}$ & $100=0$ & $\begin{array}{l}-0.1295^{\text {**** }} \\
(0.0381) \\
0.4241^{* * *} \\
(0.0622)\end{array}$ & $\begin{array}{l}-0.0533^{* *} \\
(0.0292) \\
0.5751^{* * *} \\
(0.0607)\end{array}$ \\
\hline$\delta_{1}$ & - & $\begin{array}{l}0.1080^{* *} \\
(0.0509)\end{array}$ & (5) & $\begin{array}{l}0.0626^{*} \\
(0.0344)\end{array}$ & 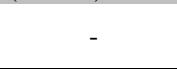 & (2) \\
\hline \multicolumn{7}{|c|}{ Bilgi Kriterleri } \\
\hline Akaike & -5.5677 & -5.6326 & -5.8924 & -5.2476 & -5.9353 & -5.4007 \\
\hline Schwartz & -5.5334 & -5.5915 & -5.8444 & -5.2134 & -5.8839 & -5.3562 \\
\hline Hannan-Quinn & -5.5549 & -5.6173 & -5.8746 & -5.2349 & -5.9162 & -5.3842 \\
\hline
\end{tabular}

Parantez içindeki rakamlar standart hataları göstermektedir. ${ }^{* * *},{ }^{* *}$, ve ${ }^{*}$ sırasıyla, $\% 1, \% 5$ ve $\% 10$ önem seviyesinde istatistiksel anlamlılı̆g 1 göstermektedir. Modellerde $\varphi_{0}$ sabit terimi, $\varphi_{1}$ terör olaylarının etkisini, $\varphi_{2}, \varphi_{3}, \varphi_{4}, \varphi_{5}$ sirasiyla AR(1), AR(2), AR(3) ve AR(4) tahmincilerini, $\theta_{1}, \theta_{2}, \theta_{3}, \theta_{4}$, sirasiyla, MA(1), MA(2), MA(3) ve MA(4) tahmincilerini, $\omega$ oynaklık modellerindeki sabit terimi, $\alpha_{1}$ ARCH etkisi, $\beta_{1}$ GARCH etkisini, $\gamma_{1}$ EGARCH işaret etkisini ve $\gamma_{2}$ EGARCH modelinde büyüklük etkisini, $\delta_{1}$ GJR-GARCH modelinde kaldıraç etkisini gösteren katsayılardır.

Modeller tahmin edildikten sonra, tahmin edilen modellerin geçerliliğini test etmek amacıyla standartlaştırılmış artıkların karelerine ilişkin 5., 10., 20. ve 50. gecikme için Q istatistiklerine bakılmıştır. Elde edilen sonuçlar Tablo 10'da gösterilmiştir. 


\section{Tablo: 10}

Standartlaştırılmış Artık Karelere İlişkin Q İstatistikleri

\begin{tabular}{lllllll}
\hline & MODEL1 & MODEL2 & MODEL3 & MODEL4 & MODEL5 & MODEL6 \\
\hline & Rgold & Rbist & Rservice & Rfinancial & Rindustrial & Rtechnology \\
\hline Q(5) & 5.12850 & 2.6131 & 2.9390 & 4.1518 & 5.7595 & 1.9142 \\
& $(0.1626)$ & $(0.4551)$ & $(0.4011)$ & $(0.2455)$ & $(0.1239)$ & $(0.5903)$ \\
Q(10) & 6.15967 & 6.9107 & 6.4594 & 8.9290 & 8.0275 & 6.2710 \\
& $(0.6293)$ & $(80.5452)$ & $(0.5959)$ & $(0.3483)$ & $(0.4307)$ & $(0.6169)$ \\
Q(20) & 8.51592 & 11.0498 & 14.8126 & 14.7877 & 11.5815 & 11.3844 \\
& $(0.9699)$ & $(0.8922)$ & $(0.6747)$ & $(0.6764)$ & $(0.8680)$ & $(0.8773)$ \\
Q(50) & 24.6616 & 27.4479 & 50.9085 & 33.5252 & 27.8884 & 46.0517 \\
& $(0.9979)$ & $(0.9925)$ & $(0.3598)$ & $(0.9439)$ & $(0.9910)$ & $(0.5530)$ \\
\hline
\end{tabular}

Parantez içindeki rakamlar olasılık değerlerini göstermektedir. ${ }^{* * *},{ }^{* *}$, ve ${ }^{*}$ sırasılyla, $\% 1, \% 5$ ve $\% 10$ önem seviyesinde istatistiksel anlamlılığı göstermektedir.

Tüm getiri serileri için oluşturulan modellere ilişkin Q istatistikleri tüm gecikmelerde \%5 önem seviyesinde istatistiki olarak anlamsız olduğu Tablo 10'dan görülmektedir. Dolayisiyla, kurulan modellerde otokorelasyon sorunu yoktur.

Negatif ve pozitif haberlerin İstanbul Altın Borsası endeks getirisi ve BIST 100 ile alt sektör endeks getirileri üzerindeki etkisini görmek amacıyla haber etkisine dayalı işaret etkilerine bakılmıştır. Tablo 11'de modellerin işaret etkilerine ilişkin istatistikler yer almaktadır.

Tablo: 11

Haber Etkisine Dayalı İşaret Etkileri

\begin{tabular}{lllllll}
\hline & MODEL1 & MODEL2 & MODEL3 & MODEL4 & MODEL5 & MODEL6 \\
\hline Bağımlı Değişken & Rgold & Rbist & Rservice & Rfinancial & Rindustrial & Rtechnology \\
\hline \multirow{2}{*}{ İşaret etkisi t testi } & 0.0885 & 1.4726 & 0.5503 & 0.7123 & 1.0833 & 0.3237 \\
& $(0.9294)$ & $(0.1408)$ & $(0.5821)$ & $(0.4762)$ & $(0.2786)$ & $(0.7461)$ \\
Negatif etki Bias t-testi & 0.9059 & 0.8454 & 1.0572 & 0.2347 & $1.7983^{*}$ & 0.8606 \\
& $(0.3649)$ & $(0.3978)$ & $(0.2904)$ & $(0.8144)$ & $(0.0721)$ & $(0.3894)$ \\
Pozitif etki Bias t testi & $2.0391^{* *}$ & 1.1623 & $3.1657^{* * *}$ & 1.4710 & $2.2798^{* *}$ & $2.9823^{* * *}$ \\
& $(0.0414)$ & $(0.2450)$ & $(0.0015)$ & $(0.1412)$ & $(0.0226)$ & $(0.0028)$ \\
Üçünün Ortak etkisi & 5.1777 & $8.2093^{* *}$ & $12.0690^{* * *}$ & $6.7322^{*}$ & $12.3943^{* * *}$ & $10.8469^{* *}$ \\
& $(0.1592)$ & $(0.0418)$ & $(0.0071)$ & $(0.0809)$ & $(0.00615)$ & $(0.0125)$ \\
\hline
\end{tabular}

Parantez içindeki rakamlar olasılık değerlerini göstermektedir. ${ }^{* * *},{ }^{* *}$, ve ${ }^{*}$ sırasıyla, $\% 1, \% 5$ ve $\% 10$ önem seviyesinde istatistiksel anlamlılı̆̆ı göstermektedir.

Tablo 11 incelendiğinde, altın piyasası için toplam işaret etkisi ve negatif işaret etkisi $\% 5$ önem seviyesinde istatistiki olarak anlamsız iken, pozitif işaret etkisi anlamlıdır. Dolayısıyla, altın piyasası endeks getiri serisi oynaklığı üzerinde pozitif haberler etkilidir. Ancak üç etkinin toplamda olan etkisi istatistiksel olarak anlamlı değildir. Diğer bir ifadeyle, model içerisinde tüm etkiler birlikte etki yaratmamakta ancak tek tek etki yaratabilmektedir.

BIST 100 endeks getiri serisi oynaklığı için işaret etkisi, negatif işaret etkisi ve pozitif işaret etkisi anlamlı değilken, üç etkinin toplamda olan etkisi \%5 önem seviyesinde istatistiksel olarak anlamlıdır. Dolayısıyla, model içerisinde etkiler tek tek ele alındığında etki yaratmamasına rağmen, tüm etkiler birlikteyken etki yaratabilmektedir. 
Hizmet, sınai ve teknoloji alt sektörleri için haber etkisine dayalı işaret etkileri incelendiğinde ise, bu sektörlerde pozitif işaret etkisinin anlamlı olduğu görülmektedir. Dolayısı ile bu sektörlerin getiri oynaklığı üzerinde pozitif haberler etkilidir.

Sınai alt sektörü için negatif ve pozitif işaret etkileri ile üç etkinin toplamda olan etkisi istatistiksel olarak anlamlıdır ve sınai endeks getiri serisi oynaklı̆̆ üzerinde pozitif haberlerin etkisi negatif haberler göre daha yüksektir.

Mali alt sektörü için işaret etkisine bakıldığında, negatif işaret etkisi ve pozitif işaret etkisi anlamsız iken, üç etkinin toplamda oynaklık üzerine olan etkisi anlamlıdır.

Çalışmada altın piyasası hariç diğer tüm piyasalarda bileşik işaret etkisinin istatistiki olarak anlamlı olduğu Tablo 11'den görülmektedir. Bu sonuçtan hareketle, ilgili sektörlerin getiri oynaklığı üzerinde tüm işaret etkilerin birlikte etki yarattığı söylenebilmektedir.

Son olarak, tahmin edilen modellerde $\mathrm{ARCH}$ etkisinin varlığının ortadan kalkıp kalkmadığını belirlemek amacıyla yeniden ARCH-LM testi uygulanmıştır ve ilgili bulgular Tablo 12'de sunulmuştur.

\section{Tablo: 12}

Modellerden Elde Edilen Artıkları İlişkin ARCH-LM Test Sonuçları

\begin{tabular}{lllllll}
\hline & MODEL1 & MODEL2 & MODEL3 & MODEL4 & MODEL5 & MODEL6 \\
\hline & Rgold & Rbist & Rservice & Rfinancial & Rndustrial & Rtechnology \\
\hline \multirow{2}{*}{ 1 Gecikme } & 0.8766 & 0.5842 & 0.1015 & 0.0565 & 0.4453 & 0.0013 \\
& $(0.4163)$ & $(0.5577)$ & $(0.7501)$ & $(0.4762)$ & $(0.5046)$ & $(0.9704)$ \\
\multirow{2}{*}{5 Gecikme } & 1.0161 & 0.5250 & 0.5876 & 0.8573 & 1.1249 & 0.2956 \\
& $(0.4065)$ & $(0.7575)$ & $(0.7095)$ & $(0.5092)$ & $(0.3450)$ & $(0.9155)$ \\
\multirow{2}{*}{10 Gecikme } & 0.6330 & 0.6624 & 0.6659 & 0.7665 & 0.8110 & 0.5563 \\
& $(0.7865)$ & $(0.7601)$ & $(0.7568)$ & $(0.6614)$ & $(0.6180)$ & $(0.8502)$ \\
\hline
\end{tabular}

Parantez içindeki rakamlar olasıllk değerlerini göstermektedir. ${ }^{* * *},{ }^{* *}$, ve ${ }^{*}$ sırasıyla, ${ }^{\%} 1, \% 5$ ve $\% 10$ önem seviyesinde istatistiksel anlamlılı̆̆ 1 göstermektedir.

Tablo 12'de getiri serileri için tahmin edilen modellerden elde edilen artıklara ilişkin 1., 5. ve 10. gecikmeler için ARCH-LM test sonuçları yer almaktadır. Tablo 12'deki sonuçlara göre modellerin hepsinde tüm gecikmelerde ARCH etkisi ortadan kalkmıştır.

\section{Sonuç}

Finansal piyasaları etkileyen en önemli unsurlardan biri belirsizliktir. Belirsizlik ortamında yatırımcılar yatırım kararlarını verirken çekimser davranmaktadırlar. Terörist saldırılar, ülkede belirsizliği arttıran önemli bir faktör olarak karşımıza çıkmaktadır. Terörist faaliyetlerde amaç ülkeyi ekonomik ve siyasi istikrarsızlığa sürüklemek, toplumsal açıdan ülkeyi büyük zarara uğratmaktır.

Bu çalışmada Türkiye'de meydana gelen terör olaylarının altın ve hisse senedi piyasası ile alt sektör endeks getirilerinin oynaklığı üzerindeki etkisi incelenmiştir. Bu amaçla İstanbul Altın Borsası endeksi ile BIST 100 ve alt sektörlerine ait günlük kapanış 
verileri kullanılmıştır. Çalışmada terörizmin finansal piyasaların oynaklığı üzerindeki etkisi, negatif ve pozitif olayların oynaklık üzerindeki etkisinin farklı olduğunu söyleyen EGARCH ve GJR-GARCH modellerinden yararlanılmıştır. Çalışmanın sonucunda, Türkiye'de meydana gelen terör olaylarının tüm getiri serileri için istatistiksel olarak anlamsız olduğu görülmüştür. Diğer bir ifadeyle analiz sonuçları, Türkiye'de altın ve hisse senedi piyasasının ülkede meydana gelen terör olaylarından etkilenmediğini göstermektedir. Bu bulgudan hareketle, Türkiye'de finansal piyasalarda terörün önemli ve anlamlı bir risk unsuru olarak ele alınamayacağı söylenebilmektedir. Bu sonuç, terör olaylarının sıklıkla meydana geldiği ülkelerde, ekonominin terör saldırıları karşısında bir tepki vermediğine işaret etmektedir.

Çalışmada oynaklığı arttırıcı ve azaltıcı yöndeki bir diğer ifadeyle negatif ve pozitif haberlerin oynaklık üzerindeki etkilerinin belirlenebilmesi için haber etkisine dayalı işaret etkileri incelenmiştir. Pozitif haberlerin altın, hizmet, sınai ve teknoloji alt sektör getiri oynaklığı üzerinde; negatif haberlerin sadece sınai alt sektör getiri oynaklığı üzerinde etkili olduğu gözlenmiştir. Çalışmada negatif, pozitif ve işaret etkilerinin birlikte hizmet ve teknoloji alt sektör getiri oynaklığı üzerinde etki yarattığı sonucuna ulaşılmıştır. Ayrıca sınai alt sektör getiri serisi oynaklığı üzerinde pozitif haberlerin etkisinin negatif haberlere göre daha yüksek olduğu tespit edilmiştir. Altın piyasası endeks getiri serisi oynaklığı üzerinde ise sadece pozitif haberlerin etkili olduğu belirlenmiştir. BIST100 getiri ve mali alt sektör getiri oynaklığı üzerinde pozitif ve negatif haberlerin anlamlı bir etkisi olmadığı sonucuna ulaşılmış ancak toplam etki dikkate alındığında ise bu durumun geçerli olmadığı görülmüştür. Analiz sonuçlarından hareketle, altın piyasasının sadece pozitif haberlere duyarlı olduğu ve finansal piyasaların endeks getiri oynaklıklarında haber etkilerinin önemli rol oynadığ1 söylenebilmektedir.

\section{Kaynaklar}

Abadie, A. \& J. Gardeazabal (2008), "Terrorism and World Economy", European Economic Review, $52,1-27$.

Ağırman, E. \& M. Özcan \& Ö. Yılmaz (2014), “Terörizmin Finansal Piyasalara Etkisi: Ampirik Bir Çalışma”, BDDK Bankacılık ve Finansal Piyasalar Dergisi, 8(2), 99-117.

Ahmed, M. \& A.M. Anwar (2016), "The Nexus between Terrorism, Infrastructure and Tourism Industry in Pakistan" International Journal of Economics and Empirical Research, 4(1), 25-31.

Akıncı, M. G.Y. Akıncı \& Ö. Yılmaz (2015), “Terörizmin Doğrudan ve Dolaylı Yatırımlar Üzerindeki Etkisi: Dış Yatırımlar Ne Kadar Telafi Edici?”, Ankara Üniversitesi SBF Dergisi, 70(1), 1-33.

Altay, H. \& A. Ekinci \& M.A. Peçe (2013), “Ortadoğu'da Terörün Ekonomik Etkileri: Türkiye, Misır ve Suudi Arabistan Üzerine Bir İnceleme”, Dumlupınar Üniversitesi Sosyal Bilimler Dergisi, 37, 267-288.

Arin, K.P. \& D. Ciferri \& N. Spagnolo (2008), "The Price of Terror: The Effects of Terrorism on Stock Market Returns and Volatility", Economic Letters, 101, 164-167.

Aurangzeb, D. \& T. Dilawer (2012), "Impact of Terrorism on Stock Returns: Evidence From Pakistan”, Universal Journal of Management and Social Sciences, 2(8), 1-23. 
Bilal, A.B. \& N.B. Talip \& I.U. Hag,q, \& M.N. Kahan \& T. Islam (2012), "How Terrorism and Macroeconomic Factors Impact on Returns: A Case Study of Karachi Stock Exchange", World Applied Sciences Journal, 19(11), 1575-1584.

Bollerslev, T. (1986), "Generalized Autoregressive Conditional Heteroskedasticity", Journal of Econometrics, 31, 307-327.

Brown, S.J. \& J.B. Warner (1985), "Using Daily Stock Returns: The Case of Event Studies”, Journal of Financial Economics, 14, 3-31.

Caruso, R. \& F. Schneider (2011), "The Socio-Economic Determinants of Terrorism and Political Violance in Western Europe", European Journal of Political Economy, 27(1), 27-49.

Chen, A.H. \& T.F. Siems (2004), "The Effects of Terrorism on Global Capital Markets", European Journal of Political Economy, 20, 349-366.

Chesney, M. \& G. Reshetar \& M. Karaman (2011), "The Impact of Terrorism on Financial Markets: An Empirical Study", Journal of Banking \& Finance, 35, 253-267.

Christofis, N. \& C. Kollias \& S. Papadamou \& A. Stagiannis (2010), “Terrorism and Capital Markets: The Effects of the Istanbul Bombings", Economics of Security Working Paper Series, 31, 1-16.

Drakos, K. (2010), “Terrorism Activity, Investor Sentiment, and Stock Returns”, Review of Financial Economics, 19, 128-135.

Emsen, Ö. \& M.K. Değer (2004), “Turizm Üzerine Terörizmin Etkileri: 1984-2001 Türkiye Deneyimi”, Akdeniz İ̈BF Dergisi, 7, 67-83.

Engle, R. (1982), “Autoregressive Conditional Heteroscedasticity with Estimates of the Variance of United Kingdom", Econometrica, 50(4), 987-1007.

Essaddam, N. \& J.M. Karagianis (2014), “Terrorism, Country Attributes, and the Volatility of Stock Returns", Research in International Business and Finance, 31, 87-100.

Feridun, M. (2011), "Impact of terrorism on Tourism in Turkey: Emprical Evidence from Turkey", Applied Economics, 43, 3349-3354.

Feridun, M. (2016), "Imoact of Education and Poverty on Terrorism in Turkey: An Empirical Investigation", Applied Research Qualtiy Life, 11, 41-48.

Freytag, A. \& J. Krüger \& D. Meierrieks \& F. Schneider (2011), "The Origins of Terrorism: CrossCountry Estimates of Socio-Economic Determinants of Terrorism", European Journal of Political Economy, 27, 5-16.

Glosten, L. \& R. Jagannathan \& D. Runkle (1993), "On the Relation between the Expected Value and the Volatility of the Nominal Excess Return on Stocks", The Journal of Finance, 48(5), 1779-1801.

Graham, M. \& V. Ramiah (2012), "Global Terrorism and Adaptive Expectations in Financial Markets: Evidence from Japanese Equity Market", Research in International Business and Finance, 26: 97-119.

Güvenek, B. \& V. Alptekin (2015), “Turistlere Yönelik Terör Saldırılarının Turizme Etkisi: Türkiye Üzerine Ampirik Bir Çalışma”, Selçuk Üniversitesi Sosyal Bilimler Meslek Yüksekokulu Dergisi, 17(1), 21-38.

Kirchgassner, G. \& J. Wolters (2007), Introduction to Modern Time Series Analysis, Berlin, Heidelberg: Springer Verlag Berlin Heidelberg. 
Kollias, C. \& S. Papadamou \& A. Stagiannis (2011), "Terrorism and Capital Markets: The Effects of the Madrid and London Bomb Attacks", International Review of Economics and Finance, 20, 532-541.

Kurt, S. \& E.T. Karagöl (2015), "The Effects of Terrorism and Defence Expenditures On Economic Growth", 6(2), 07-17; <www.ijeronline.com/Vol6issue2.php>, 01.02.2016.

Llussa, F. \& J. Tavares (2011), "Which Terror at Which Cost? On the Economic Consequences of Terrorist Attacks", Economics Letters, 110, 52-55.

Mutan, O. \& A. Topçu (2009), “Türkiye Hisse Senedi Piyasasının 1990-2009 Tarihleri Arasında Yaşanan Beklenmedik Olaylara Tepkisi”, Sermaye Piyasası Kurulu Araştırma Raporu, <http://www.spk.gov.tr/yayingoster.aspx?yid=1012\&ct=f\&action=displayfile>, 28.01.2016.

Nelson, D. (1991), “Conditional Heteroskedasticity in Asset Returns: A NewApproach”, Econometrica, 59(2), 347-370.

Parida, Y. \& P. Bhardwaj \& R. Roy (2015), "Impact of Terrorism on Tourism in India", Economics Bulletin, 35(4), 2543-2557.

Persitz, D. (2007), "The Economic Effects of Terrorism: Counterfactual Analysis of the Case of Israel", <http://www.tau.ac.il/ persitzd/TER.pdf>, 1-55, 30.11.2016.

Procasky, W.J. \& N.U. Ujah (2016), “Terrorism and Its Impact on the Cost of Debt”, Journal of International Money and Finance, 60, 253-266.

Shahbaz, M. (2013), "Linkages Betwwen Inflation, Economic Growth and Terrorism in Pakistan", Economic Modelling, 32, 496-506. 